\title{
SECOND AWARD OF MACCABAEN PRIZE AND MEDAL
}

The second Maccabaean Prize and Medal has been awarded to a student from Yale University, Mr. Robert W. Shapiro, for his essay on 'The Life and Work of James Currie'. This annual prize, which is endowed by The Maccabaeans and awarded by the Faculty of the History of Medicine and Pharmacy of the Society of Apothecaries, consists of a specially designed bronze medal, and a money prize of 25 guineas. The competition is open to anybody under thirty years of age, and the prize is awarded for the best original essay on any aspect of the history of medicine or pharmacy. Mr. Shapiro was presented with the prize by the Chairman of the Faculty, Dr. W. S. C. Copeman, at the Osler Lecture at Apothecaries' Hall on Wednesday, I8 April, before an audience of students and members of the Faculty.

Mr. Shapiro is a student at Yale University School of Medicine, where students are encouraged to interrupt their formal studies for a year of research-usually outside the United States. He has been spending a year in England carrying out research into the life and activities of James Currie (1 756-1805), an English physician who lived for a time in the American colonies, noted literary critic, and the editor of the poems of Robert Burns. The information which Mr. Shapiro collected during his stay in England has provided the material for the prize-winning essay. He returned to the United States in September to continue his clinical studies. The prize essay is to be published in full in a forthcoming issue of Medical History.

J. W.

\section{THE THOMAS SYDENHAM-BENJAMIN RUSH TRANSITION IN THE HISTORY OF PSYGHIATRY}

THERE appears to be a transition in the ideas of Thomas Sydenham ${ }^{1}$ and Benjamin Rush which is meaningful in the historical development of psychiatry. Some basic background details about these physicians have been generally accepted and should be mentioned first. Sydenham (1624-89) had broad experience as a clinician, ${ }^{2}$ recognized and described hysteria in his Dissertatio Epistolaris ( 1682 ), and noted its existence in men as well as women. Benjamin Rush (1746-1813) also was a clinician of broad experience, was very much influenced by Sydenham as shown in his autobiographical statements, ${ }^{3}$ and was indeed called 'the American Sydenham'. Goodman, ${ }^{4}$ the biographer of Rush, tells us that the latter's friend Lettsom, ${ }^{5}$ famed in his own right, believed that in some ways Rush surpassed Sydenham. In his comprehensive history of medicine, Major ${ }^{6}$ offers the opinion that Rush's Medical Inquiries and Observations upon the Diseases of the Mind is probably his most important scientific contribution. ${ }^{7}$ Zilboorg ${ }^{8}$ sees Rush as having introduced into psychiatry little that was original, and Roback ${ }^{9}$ seems lukewarm in his appraisal of Rush as a medical psychologist. Although Casamajor ${ }^{10}$ was unimpressed by Rush as the 'Father of American Psychiatry', he is nevertheless usually regarded as such and his publication of 1812 mentioned above is generally accepted as the first American psychiatric textbook, a work that retained its influence for several decades. Rush's fascinating and controversial personality is clearly delineated in biography and also in his 


\section{Newes, Notes and Queries}

letters. A brief but discerning view of the latter is available in an article by Butterfield.11

Aspects of Sydenham's views on hysteria have invited attention by others.12 In a re-evaluation of his claims regarding the frequency of hysterical disorders on a percentage basis among all forms of illness, it has been pointed out that his observations could be related to the issue of classification, and that many disorders called hysteria or hypochondriasis by him would according to present delineations be categorized among the neuroses, psychophysiologic reactions and some types of psychoses. ${ }^{13}$ It was emphasized, in this reappraisal, that aside from his description of hysteria and its recognition in both men and women, Sydenham may be granted an important niche in the history of psychiatry because of his perception of the very widespread presence of psychological illness during the course of an active practice of clinical medicine. In recent years the extensiveness of psychological illness, as a component of a wide array of problems for which patients seek help from physicians in all areas of medical practice, is being re-emphasized.

At the centennial of the American Psychiatric Association, Benjamin Rush was re-examined and several interesting features of the man and his work were highlighted. Shryock saw the psychiatry of Rush anticipating a modern orientation, perceived his interest in personality, credited him with viewing patients 'physically' as a whole, and stressed a dualistic approach in his psychological views. ${ }^{14}$

Concurrently, Adolf Meyer was pursuing his own search into the nature of Rush's contributions. ${ }^{15}$ Going beyond his psychiatric textbook, Meyer was able to demonstrate from writings including lectures on the Institutes and Practice of Medicine, that Rush was convinced of the importance of psychology in general medicine. ${ }^{16}$ In Meyer's words, Rush was credited with awareness of 'the unity of dynamics of disease', and 'mind and body as a unit'. Related to this is the reiteration by Wittels ${ }^{17}$ of certain aspects of the interest that Rush possessed in the patient as a person and in manifestations of his total functioning. Meyer's contribution to an evaluation of Rush points up his concern with the functioning of the patient as an individual, his adequate recognition of both mental and physical functioning with the significance of their interplay, and especially his approach to life in dynamic terms with stress on mind-body unity in contrast to a dualistic philosophy.

The point of the present communication is to relate the psychological elements in the practices of Sydenham and Rush on the basis of the aforementioned views. Of course Rush was influenced by others such as Cullen and Brown. ${ }^{6}$ Insofar as psychological medicine is concerned, however, there appears to be a meaningful transition between the views of Sydenham and the teachings of Rush, and it may be possible to trace the connexions more specifically. The holistic elements in Rush's thinking seem to emerge as an outgrowth of the clinical gleanings of Sydenham, although the step involved was especially large. To repeat, Rush had in general acknowledged his indebtedness to Sydenham and claimed close acquaintance with his works. Sydenham surpassed his 


\section{News, Notes and Queries}

contemporaries in the recognition of widespread importance of psychological issues in clinical practice. Rush went further in stressing the importance of the study of psychology in training for general medicine, in focusing concretely on the patient as an individual, and in combining his psychological and physiological behaviour into a holistic pattern of functioning constituting a unitary view which in recent years is again experiencing more imperatively additional emphasis in medical education.

JEROME M. SGHNEGK

\section{REFERENGES}

I. LAтнам, R. G. (1848). Works of Thomas Sydenham. London: Sydenham Society.

2. PAyne, J. F. (1900). Thomas Sydenham. New York: Longmans, Green \& Co.

3. Rush, B. (1948). The Autobiography of Benjamin Rush. Edited by G. W. Corner. Princeton: Princeton University Press.

4. Goodman, N. G. (1934). Benjamin Rush. Philadelphia: University of Pennsylvania Press.

5. Abraham, J. J. (1933). Lettsom. London: William Heinemann.

6. MajOR, R. H. (1954). A History of Medicine. Springfield, Illinois: Charles C. Thomas.

7. Rush, B. (1812). Medical Inquiries and Observations upon the Diseases of the Mind. $5^{\text {th }}$ ed. Philadelphia, 1835 .

8. Zilboorg, G. and Henry, G. W. (1941). A History of Medical Psychology. New York: W. W. Norton.

9. Rоваск, A. A. (1952). History of American Psychology. New York: Library Publishers.

10. Casamajor, L. (1943). F. nerv. ment. Dis., 98, 600.

II. Butterfield, L. H. (1946). Bull. Hist. Med., 20, 138.

12. Veitr, I. (1956). Bull. Hist. Med., 30, 233.

13. Schnegk, J. M. (1957). Amer. F. Psychiat., Ir3, 1034.

14. Shryogk, R. H. (1945). Amer. F. Psychiat., ror, 429.

15. Meyer, A. (1945). Amer. F. Psychiat., ror, 433.

16. Rush, B. (1811). Sixteen Introductory Lectures to Courses of Lectures upon the Institutes and Practice of Medicine. Philadelphia.

17. Wittels, F. (1946). Bull. Hist. Med., 20, I57.

\section{JOHN THOMAS PERGEVAL (I8o3-I876) PATIENT AND REFORMER}

THE autobiographies of the insane furnish unique opportunities for the student of the human mind to study its aberrations in pure culture as it were, untrammelled and uncoloured by those subtle but uncharted influences which result from the interaction of observer and observed in the doctor-patient relation of the formal psychiatric interview. They present mental illness portrayed in all its unvarnished detail without fear or favour, let or hindrance, save for the limitation of language to express that borderland between body and mind, thought and feeling, against the background of which so much of it is played out. Their usefulness varies only with their author's 